\title{
Atypical mycobacterias associated to acupuncuture: an integrative review
}

\author{
Juliana Rizzo Gnatta ${ }^{1}$ \\ Leonice Fumiko Sato Kurebayashi \\ Maria Júlia Paes da Silva ${ }^{3}$
}

\begin{abstract}
Aim: to evaluate evidence concerning sources or mechanisms of infection transmission of atypical mycobacteria associated with acupuncture, and the species causing infections. Method: research was performed in December 2011 in the databases of LILACS, MEDLINE, EMBASE, OvidSP and the Cochrane Library, without restrictions regarding publication date, study type or language. Results: of the 16 publications, only one identified the contamination source: diluted glutaraldehyde solution used to clean equipment. Three established likely sources: towels, hot packs or boiling tank water, and the reuse of reprocessed needles. Four indicated possible sources: contaminated needles, reuse of personal needles, patient's skin colonized by mycobacteria and reuse of needles at different sites in the same patient. Eight of the studies did not mention the sources. Conclusion: among 295 cases, M. abscessus was the pathological agent in over 96\%. Well-established control practices for infection prevention should be implemented and adapted for complementary and alternative medicine.
\end{abstract}

Descriptors: Mycobacterium; Nontuberculous Mycobacteria; Acupuncture; Complementary Therapies; Infection Control; Nursing.

\footnotetext{
1 MSc, RN, Hospital Universitário, Universidade de São Paulo, São Paulo, SP, Brazil.

2 Doctoral student, Escola de Enfermagem, Universidade de São Paulo, São Paulo, SP, Brazil.

${ }^{3} \mathrm{PhD}$, Professor Associate, Escola de Enfermagem, Universidade de São Paulo, São Paulo, SP, Brazil.
} 


\section{Introduction}

Acupuncture has been practiced for thousands of years in the East and has also increased considerably in the West $^{(1)}$. This practice has been used to treat digestive(2), psychosomatic, menstrual, allergy, alcohol and drugs rehabilitation problems ${ }^{(3)}$. It is considered a complementary health therapy $(\mathrm{CHT})$ that makes use of an invasive intervention and for this reason some concern is necessary in relation to skin antisepsis. The future of acupuncture in the West largely depends on the safety and efficacy of the treatment. The acupuncturist is responsible for the non-contamination of procedures and for preventing outbreaks when practicing the technique. In this regard, this study highlights the infections caused by nontuberculous mycobacteria, also denominated atypical mycobacteria(4), which are implicated as possible infectious agents in acupuncture procedures.

Bacteria of the genus Mycobacterium are aerobic, immotile, non-encapsulated bacilli, which do not sporulate and contain a high lipid content, mainly in the cells wall, making permeability difficult for dye solutions, water or microbicidal agents ${ }^{(5)}$. There are approximately 50 species of mycobacterium that have been identified as causing disease in humans, however the incidence of specific diseases caused by atypical mycobacteria has increased with the advent of the HIV/AIDS and the use of immunosuppressive therapies( ${ }^{(6)}$.

These infections can be included under the category of infections related to healthcare (IRHC) and nurses should consider this issue and discuss security measures for invasive procedures. In Brazil, nurses are also required to perform $\mathrm{CHTs}$, including acupuncture, under specific regulating legislation, which also establishes the complementary therapies as an specialty and/or professional qualifications of nursing, after a specialization course with a workload of 360 hours has been completed ${ }^{(7)}$.

The Brazilian Nursing Ethics Code, in article $17^{(8)}$, states that it is the nurse's ethical and moral obligation to only assume a responsibility when being capable of performing it safely for oneself and for the client, aiming for the maximum benefits and minimum risk. The nurse also has an important role regarding infection control, as established by the professional law practice ${ }^{(9)}$ and the national legislation, which requires the presence of at least one nurse on the Infection Control Commission of hospitals(10).

The integrative review consists in an exhaustive systematic search of the scientific literature aiming to produce an overview of complex concepts, theories or relevant health problems from existing studies ${ }^{(11)}$. It is a research methodology recommended by EvidenceBased Practice (EBP), which indicates that the best scientific evidence produced by studies should be applied during the decision making process, linking the clinical practice to quality care(12). Thus, this study proposes an integrative review of literature to assess the association of atypical mycobacterial infections with acupuncture.

A review of this subject was considered due to the relevance $\mathrm{CHT}$ has assumed worldwide, especially acupuncture, as well as due to a warning about the occurrence of IRHC by mycobacteria, allowing acupuncturists to improve the practice with less risk to clients and to contribute to reduce costs to the health system. Importantly, the damage related to the selfesteem, as well as the psychological and physical impacts on the patient, such as pain and suffering caused by the treatment of mycobacterial infection are immeasurable to individuals. This study aimed to evaluate evidence in the scientific literature on the major sources or mechanisms of infections transmission caused by atypical mycobacteria associated with the acupuncture procedure and to determine the main species causing infections.

\section{Methods}

The method used was an integrative review of literature and the following methodologies were defined: establishment of the research question and objectives literature studies search, sample selection, analysis of the included studies, discussion of the results, presentation of the results and finally, the summarization of knowledge through an integrative review ${ }^{(12)}$.

The question studied was: "What are the main sources or mechanisms involved in infection transmission associated with acupuncture caused by atypical mycobacteria and what are the main species causing infection?"

This review was performed in December 2011 with indexed descriptors ("Mycobacterium OR Mycobacteria, Atypical OR Mycobacterium Infections OR Mycobacterium Infections, Atypical" AND "Acupuncture OR Acupuncture Therapy OR Acupuncture, Ear") in the databases of LILACS (Latin American and Caribbean Health Sciences) via BIREME, MEDLINE (Medica Literature Analysis and Retrieval System on-line) via PubMed, EMBASE, OvidSP and in databases available from The Cochrane Library via BIREME and OvidSP - 
without restrictions regarding publication date, nature of study or language. References cited in the articles were analyzed to identify publications not found by the electronic search strategy.

Any type of publication was included which reported infections caused by atypical mycobacteria after acupuncture with needles had been performed. Publications regarding infections associated to mesotherapy procedures were excluded, as were expert opinions or editorials. The final sample consisted of 16 publications (Table 1 ), which were analyzed in full. As shown in Table 1, two publications ${ }^{(6,13)}$ were excluded due to the exclusion criteria. To perform the data collection a validated instrument ${ }^{(14)}$ was used that was adapted to allow the production of a summary table of the publications included (Figure 1).

Table 1 - Selection of publications from databases and references of other publications according to the criteria established for inclusion of studies in this integrative review. Brazil, 2011

\begin{tabular}{|c|c|c|c|c|c|c|}
\hline Databases & Found & Pre-selected & Selected & $\begin{array}{l}\text { Excluded due } \\
\text { to repetition }\end{array}$ & Included & Excluded \\
\hline Embase & 06 & 06 & 06 & - & 06 & - \\
\hline MEDLINE & 45 & 15 & 15 & 05 & 09 & 01 \\
\hline OvidSP & 28 & 03 & 03 & 01 & 01 & 01 \\
\hline Cochrane Library & 02 & - & - & - & - & - \\
\hline LILACS & 10 & - & - & - & - & - \\
\hline CINAHL & 03 & 02 & 02 & 02 & - & - \\
\hline Bibliographic Reference & - & - & - & - & - & - \\
\hline Total & 94 & 26 & 26 & 08 & 16 & $02^{(6,13)}$ \\
\hline
\end{tabular}

\section{Results}

The 16 publications included in this review were from international journals of the medical area and the earliest was published in 2001. Among the studies included in this review, six (37.5\%) were published in area of dermatology (P3; P4; P6; P8; P9; P13), five $(31,2 \%)$ in journals of infection (P7; P11; P12; P14; P15), two in general medical journals (P1; $P 5)$, two in clinical microbiology periodicals (P2; P10) and one in the orthopedics area (P16). The majority of the studies, about $50.0 \%$, were from South Korea (8 publications), followed by China and Spain, with two publications in each country. Portugal, Canada, Venezuela and Brazil presented one publication per country.

As can be seen in Figure 1, the predominant study design was the case report. Although there are ten publications of this type, P1 and P2 refer to the same case of atypical mycobacterial infection. The second most frequent type of study was reports of outbreaks, which were presented in three publications, although P6 and P7 refer to the same outbreak caused by Mycobacterium abscessus that occurred in a clinic. There was only one case-control study (P13) and one observational study (P10 and P11 refer to the same patients).

The evidence levels of the publications are presented according to study design ${ }^{(15)}$. There were three studies that have evidence level 4 (Figure 1): a case-control design (P12) and two publications that refer to the same observational study (P10 and P11). Thirteen publications showed evidence level 6, with reports of outbreaks (P6; P7 - for the same outbreak; and P8) or case reports (P1; P2; P3; P4; P5; P9; P13; P14; P15; P16).

\begin{tabular}{|c|c|c|c|c|c|c|}
\hline Study & $\begin{array}{l}\text { Country I } \\
\text { Year }\end{array}$ & $\begin{array}{l}\text { Type of } \\
\text { Study }\end{array}$ & Subjects & Mycobacteria & Source & Recommendations / Conclusions \\
\hline $\begin{array}{l}\mathrm{P} 1^{(16)} \\
\mathrm{P} 2^{(3)}\end{array}$ & $\begin{array}{l}\text { China, } \\
\text { 2001-P1 } \\
\text { 2002-P2 }\end{array}$ & $\begin{array}{l}\text { Case report } \\
\text { (both) }\end{array}$ & $\begin{array}{l}\text { One woman ( } 79 \\
\text { years) and } 3 \text { men } \\
\text { (62, } 72 \text { and } 21 \text { years } \\
\text { - the latter being } \\
\text { immunosuppressed) }\end{array}$ & $\begin{array}{l}\text { M. chelonae } \\
\text { (2) } \\
\text { M. nonchoro- } \\
\text { mogenicum } \\
\text { (2) }\end{array}$ & Not cited & $\begin{array}{l}\text { Hand hygiene of the professional } \\
\text { with alcoholic } \mathrm{CHX}^{*} \text { or } \mathrm{PVPl}^{+} / \text {wash } \\
\text { patients with soap and water if } \\
\text { necessary / antisepsis of the skin with } \\
\text { alcohol } 75 \% \text { and wait } 60 \text { seconds }\end{array}$ \\
\hline$P 3^{(17)}$ & $\begin{array}{l}\text { Spain, } \\
2003\end{array}$ & Case report & $\begin{array}{l}\text { One woman, } \\
58 \text { years, } \\
\text { immunocompetent }\end{array}$ & M. chelonae & $\begin{array}{l}\text { Possible: } \\
\text { contaminated } \\
\text { needles }\end{array}$ & No recommendations \\
\hline $\mathrm{P} 4^{(18)}$ & $\begin{array}{l}\text { Portugal, } \\
2003\end{array}$ & Case report & $\begin{array}{l}\text { One woman, } 41 \\
\text { years old }\end{array}$ & M. fortuitum & $\begin{array}{l}\text { Reuse of needles } \\
\text { in the same client }\end{array}$ & $\begin{array}{l}\text { Caution in relation to potential } \\
\text { contamination }\end{array}$ \\
\hline
\end{tabular}




\begin{tabular}{|c|c|c|c|c|c|c|}
\hline Study & $\begin{array}{l}\text { Country I } \\
\text { Year }\end{array}$ & $\begin{array}{l}\text { Type of } \\
\text { Study }\end{array}$ & Subjects & Mycobacteria & Source & Recommendations / Conclusions \\
\hline$P 5^{(19)}$ & $\begin{array}{l}\text { Spain, } \\
2004\end{array}$ & Case report & $\begin{array}{l}\text { One woman, } 71 \\
\text { years }\end{array}$ & M. chelonae & Not cited & $\begin{array}{l}\text { Atypical mycobacterial infections } \\
\text { associated to acupuncture shown } \\
\text { to be an emerging problem, which } \\
\text { should be included in differential } \\
\text { diagnosis of skin infections associated } \\
\text { with acupuncture procedures }\end{array}$ \\
\hline $\begin{array}{l}P 6^{(20)} \\
P 7^{(1)}\end{array}$ & $\begin{array}{l}\text { South } \\
\text { Korea, } \\
2005-P 6 \\
2006-P 7\end{array}$ & $\begin{array}{l}\text { Outbreak } \\
\text { report (both) }\end{array}$ & $\begin{array}{l}40 \text { patients with an } \\
\text { mean age of } 43 \\
\text { years, being } 7 \text { men } \\
\text { and } 33 \text { women }\end{array}$ & M. abscessus & $\begin{array}{l}\text { Hot packs or } \\
\text { towels for hot } \\
\text { packs or boiling } \\
\text { tank water }\end{array}$ & $\begin{array}{l}\text { Hand hygiene of professionals with } \\
\text { alcohol CHX or PVPI / "sterilization" } \\
\text { of the skin with alcohol or PVPI } \\
\text { / "sterilization" of equipment and } \\
\text { environment / guidelines and } \\
\text { education }\end{array}$ \\
\hline$P 8^{(21)}$ & $\begin{array}{l}\text { Canada, } \\
2006\end{array}$ & $\begin{array}{l}\text { Outbreak } \\
\text { report }\end{array}$ & $\begin{array}{l}32 \text { subjects ( } 2 \text { men, } \\
30 \text { women, mean } \\
\text { age: } 49 \text { years, none } \\
\text { immunosuppressed). } \\
5 \text { suspected, } 6 \\
\text { confirmed and } 21 \\
\text { probable cases }\end{array}$ & M. abscessus & $\begin{array}{l}\text { Reuse of } \\
\text { needles that } \\
\text { were improperly } \\
\text { disinfected in } \\
\text { glutaraldehyde } \\
\text { diluted with tap } \\
\text { water }\end{array}$ & $\begin{array}{l}\text { It is important to appropriate the } \\
\text { practice of infection control and the } \\
\text { sterilization of materials in health } \\
\text { services, including in services } \\
\text { that practice alternative and } \\
\text { complementary therapies }\end{array}$ \\
\hline $\mathrm{Pg}(22)$ & $\begin{array}{l}\text { South } \\
\text { Korea, } \\
2009\end{array}$ & Case report & $\begin{array}{l}\text { One woman, } 59 \\
\text { years, history } \\
\text { of pulmonary } \\
\text { tuberculosis } \\
\text { (resolved) }\end{array}$ & M. abscessus & Not cited & $\begin{array}{l}\text { Includes atypical mycobacteria in } \\
\text { differential diagnosis of cases with } \\
\text { the occurrence of multiple nodules } \\
\text { associated to acupuncture }\end{array}$ \\
\hline $\begin{array}{l}\mathrm{P} 10^{(23)} \\
\mathrm{P} 11^{(24)}\end{array}$ & $\begin{array}{l}\text { South } \\
\text { Korea, } \\
\text { 2009-P10 } \\
\text { 2011-P11 }\end{array}$ & $\begin{array}{l}\text { Observational } \\
\text { study }\end{array}$ & $\begin{array}{l}\text { About } 100 \text { cases } \\
\text { of which only } 52 \\
\text { participated in the } \\
\text { study }\end{array}$ & M. abscessus & Not cited & $\begin{array}{l}\text { Only related to antibiotic: moxifloxacin } \\
+ \text { clarithromycin combination resulted } \\
\text { in more rapid resolution of the skin } \\
\text { lesions compared with clarithromycin } \\
+ \text { amikacin }\end{array}$ \\
\hline $\mathrm{P} 12^{(25)}$ & $\begin{array}{l}\text { South } \\
\text { Korea, } \\
2010\end{array}$ & $\begin{array}{l}\text { Outbreak } \\
\text { report and } \\
\text { Case-control }\end{array}$ & $\begin{array}{l}\text { Reported: } 109 \text { cases } \\
\text { / Case-control } \\
\text { study: } 70 \text { cases } \\
\text { and } 106 \text { controls }\end{array}$ & M. abscessus & $\begin{array}{l}\text { Diluted } \\
\text { glutaraldehyde } \\
\text { solution prepared } \\
\text { months before } \\
\text { and used } \\
\text { to disinfect } \\
\text { equipment }\end{array}$ & $\begin{array}{l}\text { Preparation of the skin with } \\
\text { ethanol waiting for the drying time } \\
\text { recommended by the literature / } \\
\text { adequate management during dilution } \\
\text { of glutaraldehyde }\end{array}$ \\
\hline $\mathrm{P} 13^{(26)}$ & $\begin{array}{l}\text { South } \\
\text { Korea, } \\
2010\end{array}$ & Case report & $\begin{array}{l}\text { Three cases: two } \\
\text { women }(52 \text { and } 65 \\
\text { years) and one man } \\
\left(62 \text { years }+\mathrm{DM}^{\ddagger}\right)\end{array}$ & $\begin{array}{l}\text { M. abscessus } \\
\text { M. fortuitum } \\
\text { M. avium } \\
\text { complex }\end{array}$ & Not cited & $\begin{array}{l}\text { Suspected atypical mycobacterial } \\
\text { infections in cases of persistent and/ } \\
\text { or skin lesions resistant to treatment, } \\
\text { especially in immunocompromised }\end{array}$ \\
\hline $\mathrm{P} 14^{(27)}$ & $\begin{array}{l}\text { Venezuela } \\
2010\end{array}$ & Case report & $\begin{array}{l}\text { One woman, } 23 \\
\text { years old }\end{array}$ & M. fortuitum & $\begin{array}{l}\text { Possible: } \\
\text { contaminated } \\
\text { needles }\end{array}$ & $\begin{array}{l}\text { Quaternary ammonium is a } \\
\text { disinfectant widely used in Venezuela } \\
\text { for skin antisepsis and disinfection } \\
\text { of instrumentals. This solution can } \\
\text { be a possible transmission source } \\
\text { of atypical mycobacteria causing } \\
\text { infections }\end{array}$ \\
\hline $\mathrm{P} 15^{(28)}$ & $\begin{array}{l}\text { Brazil, } \\
2011\end{array}$ & Case report & $\begin{array}{l}\text { One transplanted } \\
\text { man, } 59 \text { years old }\end{array}$ & $\begin{array}{l}\text { M. } \\
\text { haemophilus }\end{array}$ & $\begin{array}{l}\text { Possible: } \\
\text { patient's skin } \\
\text { colonized or } \\
\text { infected by } \\
\text { mycobacteria and } \\
\text { reuse of needles } \\
\text { at different sites in } \\
\text { the same patient } \\
\text { / contaminated } \\
\text { needles }\end{array}$ & $\begin{array}{l}\text { There are failures in the practice of } \\
\text { infection control by acupuncturists / } \\
\text { use of disposable needles is indicated } \\
\text { / potential risks of acupuncture } \\
\text { should be recognized, especially in } \\
\text { immunocompromised patients }\end{array}$ \\
\hline $\mathrm{P} 16^{(29)}$ & $\begin{array}{l}\text { South } \\
\text { Korea, } \\
2011\end{array}$ & Case report & $\begin{array}{l}\text { One woman, } 56 \\
\text { years old }\end{array}$ & M. abscessus & Not cited & $\begin{array}{l}\text { Direct inoculation of Mycobacterium, } \\
\text { such as contaminated needles } \\
\text { during acupuncture, can } \\
\text { cause mycobacteriosis even in } \\
\text { immunocompetent patients }\end{array}$ \\
\hline
\end{tabular}

*CHX: chlorhexidine; +PVPI: povidone-iodine; ҒDM: Diabetes mellitus

Figure 1 - Characteristics of the studies included in this review according to country, year of publication, type of study, number of affected subjects, species of mycobacteria, infection source and recommendations by authors. Brazil, 2011 
Among the 295 cases of patients who developed atypical mycobacterial infections associated with acupuncture a predominant proportion of the female sex was reported (83.0\%, 162 women), not including the 100 cases from P10 and P11. These last two studies reported the occurrence of 100 mycobacteriosis cases, however, data only from the 52 patients who received the antimicrobial therapy, were described. In P10 and $\mathrm{P} 11$ the female sex was also predominant (84.6\%).

The mean age was 43 years in P6 and P7 (which refer to the same outbreak); in P8 and P12 the mean was 49 years; and the mean age of the subjects in the other studies, except $\mathrm{P} 10$ and $\mathrm{P} 11$, was approximately 55 years. In $\mathrm{P} 10$ and $\mathrm{P} 11$ the mean age of the 52 patients was 50 years.

All the cases described in Figure 1 were successfully cured after treatment with the appropriate antibiotics. Mycobacterium abscessus was responsible for $96.0 \%$ of the infections. M. chelonae, M. fortuitum and $M$. nonchoromogenicum caused four, three and two infections, respectively. M. avium complex and M. haemophilus were each identified in one case of mycobacterial infection associated with acupuncture. Only one of the 16 publications (7.1\%) identified the outbreak source: M. abscessus was found in a dilute solution of glutaraldehyde, which was prepared several months before and was used to clean equipment (P12). Probably, during the disinfection process, the solution contaminated electrodes used for interferential current and low-frequency therapies. The authors suspected that the mycobacteria, which were present in the contaminated solution, may have originated from the tap.

Three publications indicated sources such as towels for hot packs, hot towels or water boiling tank (P6/P7 - refer to the same outbreak); reuse of needles improperly disinfected with glutaraldehyde diluted in tap water among different patients (P8).

Another four publications mentioned possible sources of mycobacteria as: contaminated needles (P3; P14); reused needles that were brought by the client for each acupuncture session (P4); the patient's skin being colonized or a pre-existent subcutaneous infection caused by mycobacteria and the reuse of needles in different locations in the same patient, in this case, the contaminated needles spread the mycobacteria to other sites or reused needles were contaminated from an unknown environmental reservoir $(P 15)$. The remaining eight publications (P1; P2; P5; P9; P10; P11; P13; P16) did not mention the sources for atypical mycobacterial infections associated with acupuncture procedures.
Article P2 included four cases of atypical mycobacterial infection associated with acupuncture, between 1999 and 2000, in which the patients were hospitalized and includes the case of a single patient who was described in P1 (a 79 year old woman). In these two reports the possible contamination sources are not investigated and the conditions of the clinic in which the sessions of acupuncture were performed are not described. Article P2 also shows that two species of mycobacteria incubated in $75 \%$ alcohol survived for up to 45 seconds, thus the authors indicated antisepsis of skin for at least 60 seconds.

Article P3 reports that the acupuncturist did not help in identifying the possible infection source, as he did not want to cooperate with the case. The authors only mention that one likely contamination source could have been through needles contaminated by $M$. chelonae. In addition, this study claims to be the first to report an infection case by this bacterium associated with acupuncture, however, the references found P1 and P2 to be earlier than 2003.

Article P4 reports that the needles used in the acupuncture therapy were brought by the patient and were for personal use. However the needles were reused in the same patient and this was probably the cause of the infection.

Articles P5 and P9 reported a case of infection with M. chelonae and M. abscessus, respectively, and warn that mycobacterial should be included in the differential diagnosis of skin infections associated with acupuncture procedures.

Articles P6 and P7 reported the occurrence of the same outbreak of $M$. abscessus in 40 patients submitted to acupuncture in an Oriental medicine clinic. All 35 environmental samples taken to check the possible outbreak source were negative. However, local authorities found that one month before the investigation took place; the clinic had changed the towels and hot water bottles, and sterilized the equipment used to heat the water in which the towels were soaked and which was also used to fill the bags. After these measures no further cases of infection with $M$. abscessus were reported. It was therefore inferred that the skin of the patients had been infected with mycobacteria before or after acupuncture, during therapy with bags of hot water used in the complementary therapy session. Another hypothesis would be contamination of needles by any possible contact with contaminated tap water.

Article P8 reports that there was an outbreak of M. abscessus between April and December 2002 in two 
different clinics, where one acupuncturist attended 168 clients. Interviews with the patients and therapist found that the needles were reprocessed in a glutaraldehyde solution although, as this disinfectant solution was no longer available for analysis, it was not possible to assess the presence of mycobacteria.

Articles P10 and P11 reported the same outbreak with approximately 100 subjects affected, 52 participated in an intervention study to compare the association of clarithromycin + amikacin with that of moxifloxacin + clarithromycin. The second combination presented a significantly shorter duration of treatment than the first solution. The cause of the outbreak was not mentioned.

In another outbreak report, article P12 described a case-control study. It identified as risk factors the duration of acupuncture treatment, the number of needles inserted, the use of interferential therapy or low-frequency equipment and the application of hot water packs.

A retrospective study (P13) investigated the clinical and microbiological characteristics of several skin infections caused by atypical mycobacteria which were treated at a hospital between 1995 and 2008. Three of the 29 cases analyzed were due to acupuncture procedures, however, there was no mention of the infection source.

Article P14 did not identify the outbreak source, though the authors refer to contaminated needles used in the acupuncture procedure as a possible source. In a literature review the authors found seven articles, corresponding to $\mathrm{P} 1, \mathrm{P} 2, \mathrm{P} 3, \mathrm{P} 6, \mathrm{P} 7, \mathrm{P} 8$ and $\mathrm{P} 12$ of this integrative review. The authors mention that, although they do not have any proof, they believe that the widespread use of quaternary ammonium disinfectant for the "sterilization" of instruments is a possible risk factor for infections caused by mycobacteria.

The patient described in P15 reported that antisepsis of the skin was not carried out prior to the procedure and that the needles were reused several times in different places in the body, which led the authors to establish possible routes of $M$. haemophilum which caused the infection.

Article P16 reported a case of $M$. abscessus after the patient receive three consecutive days of acupuncture on the bilateral knees. This woman presented no evidence of other diseases.

\section{Discussion}

Acupuncture is considered a safe procedure in general(25). However, in the last decade, reports of infection transmission have increased considerably, including those of atypical mycobacteria(6). Only 16 publications were found in the scientific literature related to the proposed theme, even without setting limits on publication date, type of study or language. This raises two questions: a) Is there underreporting of cases of mycobacterial infections in Eastern and Western countries? b) Do cases of atypical mycobacterial infection go underreported in the literature due to the fact that methods for microorganism identification became more accurate after the year 2000?

Although this review was mainly composed of studies with low levels of evidence, it is important to emphasize that cases and even outbreaks (P6; P7; P8) of atypical mycobacterial infections are happening. Females were predominant in the development of mycobacterial infections perhaps because they constitute the majority of acupuncture patients.

The infections were caused by six species of atypical mycobacteria, three of them, species M. abscessus, $M$. chelonae and $M$. fortuitum, are classified as rapid growth $^{(4)}$. These microorganisms were responsible for about $98.6 \%$ of the infections included in this review and are commonly found in treated water, soil and the environment(5), which demonstrates a direct relationship with the identified, probable or possible infection sources, in the studies described.

Of the 16 publications included in this integrative review only one $(6.2 \%)$ identified the definite source of the outbreak: M. abscessus (P12). Three publications (P6; P7; P8) established the probable sources and two of them reported the same outbreak (P6 and P7). In another three articles the possible sources of mycobacteria were described (P3; P4; P14). The eight remaining publications (P1; P2; P5; P9; P10; P11; P13; P16), corresponding to $50.0 \%$ of the studies, did not mention anything about the sources that may have caused the cases of atypical mycobacterial infections associated with acupuncture procedures. This indicates that there are failings in the investigation process of outbreaks or in the clinical conduct of the treatment, not only in clinics where alternative or complementary therapies are practiced but also in conventional medical services that screen and treat patients who develop infection. In addition these potential sources are associated with failures during the process of disinfecting instruments, inadequate preparation of disinfectants, not performing antisepsis of the skin and/or hand hygiene.

A routine that should be strengthened for practitioners of acupuncture is the importance of using 
disposable needles. This procedure is recommended by the Food and Drug Administration (FDA) ${ }^{(30)}$. Although this practice is being recommended, even in a guideline(31) developed precisely for infection control in acupuncture, the reuse of needles after sterilization is still allowed. The guideline(31) mentions the need for and types of sterilization, nevertheless does not specify which one should be indicated nor how to apply the methods. The use of personal needles is also not indicated, as the material does not undergo to any type of reprocessing that ensures sterility. Also, there is no control of the storage once the patient is responsible for the needles. This indicates the need for a revision(3), elaborating a new guideline for infection control and prevention in acupuncture as established by regulators and through recommended infection control and prevention practices.

Some basic concepts concerning infection prevention, such as disinfection, sterilization and antisepsis, are still unclear, even for professionals working with healthcare. Articles P5 and P6 propose that sterilization of the environmental and patient's skin be performed, in other words, materials completely unfeasible to sterilize. Article P14 refers to the "sterilization" of instruments performed using quaternary ammonium disinfectant, however, this solution is suitable only for low-level disinfection. It is worth noting that this type of disinfection is indicated for items or surfaces that only come into contact with intact skin $^{(32)}$. Moreover, low-level disinfection has no action on Mycobacterium tuberculosis(32) and, probably, on other bacilli from the same genus. Therefore the use of sterile needles for acupuncture is more appropriate.

Proposals such as hand hygiene with alcoholic chlorhexidine or povidone-iodine (PVPI) are unnecessary. Acupuncture can be compared with recommendations for intravascular insertion catheters described by the Centers for Disease Control and Prevention of the U.S.A. i.e., simple hand hygiene with soap and water or alcohol gel hand sanitizer before performing the procedure (Category $1 \mathrm{~A}$ ), aseptic technique ensuring the sterility of the material (Category $1 \mathrm{~A}$ ) and skin antisepsis with alcohol solution (Category $1 A)^{(33)}$. The indication of Category $1 \mathrm{~A}$ means that all these procedures are strongly recommended for implementation and supported by well-designed experimental, clinical, or epidemiologic

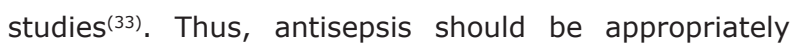
performed with an alcohol solution and the time required for antiseptic agent action taken into account, as is recommended by Category $1 \mathrm{~A}^{(33)}$. Especially considering that one of the studies included in this review found that some species of atypical mycobacteria can survive for up to 45 seconds in contact with alcohol ${ }^{(3)}$. These safety measures associated with the use of sterile disposable needles are sufficient for the puncture to be performed safely by a professional, preventing mycobacterial infection outbreaks related to this procedure.

Thus, the importance is emphasized of guidance for students that are doing alternative and complementary therapy courses and for acupuncture practitioners in their workplaces. Regarding nurses, it is expected that the experience of infection control practice in hospitals can contribute to a safe acupuncture practice. The presence of an infection control specialist nurses has been universally seen as an essential measure for infection control programs to be effective ${ }^{(34)}$, which can also be applied to establishments that practice complementary medicine.

It is emphasized that the studies included in this review ( $P 1$ - P16) isolated and identified the Mycobacterium microorganism from different sources, however, no molecular research was carried out in order to confirm the clonal origin. This type of investigation can be explored in the case of new outbreaks, confirming the clonal origin of the bacteria and contributing to the advancement of knowledge of this subject.

It is important to emphasize the role of the nurse as educator in infection prevention and control and their possible role as technical managers in the IRHC control program and clinics which perform CHTs, as well as in institutions which work with complementary medicine. Therefore, the nursing professional acupuncturist, with a solid training in infection control, can take part in the prevention and control of IRHC in complementary health practices. Furthermore, it is important to study not only the most effective and appropriate antibiotic therapy for the treatment of mycobacteria, but also to investigate the probable infection sources when cases of mycobacteria associated with acupuncture are detected.

\section{Conclusion}

There are several cases and outbreaks reported in the literature about infection by atypical mycobacteria associated with acupuncture procedures, especially those of rapid growth, however, the majority of publications did not refer to the infection source. Only one study identified a diluted glutaraldehyde solution prepared several months before the use that was applied to clean the equipment as the definite infection source. Six publications suggest probable or possible 
sources, such as objects or utensils and contaminated needles, reuse of personal needles, reuse of needles on various sites in the same patient and also the reuse of needles, which were disinfected in glutaraldehyde diluted incorrectly in tap water, on different patients. M. abscessus was the microorganism responsible for the majority of infections. Well-established control and infection prevention practices, which are recommended by regulators, should be implemented and adapted by nurses for complementary and alternative medicine.

\section{References}

1. Song JY, Sohn JW, Jeong HW, Cheong HJ, Kim WJ, Kim MJ. An outbreak of post-acupuncture cutaneous infection due to Mycobacterium abscessus. BMC Infect Dis. $2006 ; 6: 6$.

2. Lyn Patrick. Gastroesophageal reflux disease (GERD): a review of conventional and alternative treatments. Alt Med Rev. 2011;16(2):116-33.

3. Woo PC, Leung KW, Wong SS, Chong KT, Cheung EY, Yuen KY. Relatively alcohol-resistant mycobacteria are emerging pathogens in patients receiving acupuncture treatment. J Clin Microbiol. 2002;40:1219-24.

4. Runyon EH. Anonymous mycobacteria in pulmonary disease. Med Clin North Am. 1959;43(1):273-90.

5. Fontana RT. The Mycobacterias of rapid growth and the hospital infection: a public health problem. REBEn. 2008;61(3):371-6.

6. Woo PC, Lin AW, Lau SK, Yuen KY. Acupuncture transmitted infections. BM] [periódico na Internet]. 2010 [acesso 27 maio 2012];18:340:c1268. Disponível em: http://www.bmj.com/content/340/bmj.c1268.extract

7. Resolução COFEN 197/1997 (BR). Estabelece e reconhece as Terapias Alternativas como especialidade e/ou qualificação do profissional de Enfermagem. 1997. [acesso 18 abr 2012]. Disponível em: http://site. portalcofen.gov.br/node/4253

8. Resolução COFEN n. 240/2000 (BR). Aprova o Código de Ética dos Profissionais de Enfermagem e dá outras providências. In: Conselho Regional de Enfermagem de São Paulo (COREN-SP). Documentos básicos de enfermagem: enfermeiros, técnicos e auxiliares. São Paulo; 2001:277-89.

9. Lei n. 7.498, de 25 de junho de 1986 (BR). Dispõe sobre a regulamentação do exercício da enfermagem e dá outras providências. In: Conselho Regional de Enfermagem de São Paulo (COREN-SP). Documentos básicos de enfermagem: enfermeiros, técnicos e auxiliares. São Paulo; 2001. p. 6-41.
10. Portaria no 2616/MS/GM, de 12 de maio de 1998 (BR). Diário Oficial da União [periódico na Internet]. 12 maio 1998. [acesso 18 abr 2012]. Disponível em http://www.anvisa.gov.br/legis/portarias/2616_98.htm 11. Whittemore $R$, Knafl $K$. The integrative review: updated methodology. J Adv Nurs. 2005;52(5):546-53. 12. Mendes KDS, Silveira RCCP, Galvão CM. Integrative literature review: a research method to incorporate evidence in health care and nursing. Texto Contexto Enferm. 2008;17(4):758-64.

13. Carbonne A, Brossier F, Arnaud I, Bougmiza I, Cambau E, Meningaud JP, et al. Non-tuberculous mycobacterial infections related to cosmetic and medica procedures and acupuncture [abstract]. In: European Society of Clinical Microbiology and Infectiotius Diseases; Abstracts de 20th European Congress of Clinical Microbiology and Infectious Diseases; 2010 Apr 10-13; Vienna, Austria. United Kingdom (Oxford): Blackwell Publishing; 2010. S63.

14. Ursi ES, Galvão CM. Perioperative prevention of skin injury: an integrative literature review. Rev. Latino-Am. Enfermagem. 2006;14(1):124-31.

15. Melnyk BM, Fineout-Overholt E. Making the case for evidence-based practice. In: Melnyk BM, FineoutOverholt E. Evidence based practice in nursing \& healthcare. A guide to best practice. 2nd ed. Philadelphia: Lippincot Williams \& Wilkins; 2011. p. 3-24.

16. Woo PC, Li JH, Tang W, Yuen K. Acupuncture mycobacteriosis. N Engl J Med. 2001;345:842-3.

17. Ara M, de Santamaría CS, Zaballos P, Yus C, Lezcano MA. Mycobacterium chelonae infection with multiple cutaneous lesions after treatment with acupuncture. Int J Dermatol. 2003;42(8):642-4.

18. Cordeiro MR, Mascarenhas R, Reis JP, Tellechea O, Figueiredo A. Mycobacterial infection after acupunture. JEADV. 2003;17 Suppl 3:186.

19. Gomez de la Torre R. Hidalgo Garcia F. Milla Crespo A. Fernandez Bustamante J. Cutaneous infection by Mycobacterium chelonaeafter treatment with acupuncture [letter]. Med Clin (Barc). 2004;122(16):636.

20. Ryu $\mathrm{HJ}$, Kim $\mathrm{WJ}$, $\mathrm{Oh} \mathrm{CH}$, Song $\mathrm{HJ}$. Iatrogenic Mycobacterium abscessus infection associated with acupuncture: clinical manifestations and its treatment. Int J Dermatol. 2005;44(10):846-50.

21. Tang $P$, Walsh S, Murray C, Alterman C, Varia M, Broukhanski G, et al. Outbreak of acupuncture-associated cutaneous Mycobacterium abscessus infections. J Cutan Med Surg. 2006;10(4):166-9.

22. Cho HJ, Lee DY, Lee JH, Yang JM, Lee ES. A case of Mycobacterium abscessus skin infection caused by 
multiple acupunctures [letter]. Clin Exp Dermatol. 2010;35(4):444-5.

23. Park DW, Kim MJ, Choi WS, Heo YS, Son SW, Yoon YK, et al. Clarithromycin and amikacin versus clarithromycin and moxifloxacin as the treatment for post-acupuncture cutaneous infection due to Mycobacterium abscessus: prospective observation study. Clin Microbiol Infect. 2009;15 Suppl 4:S395.

24. Choi WS, Kim MJ, Park DW, Son SW, Yoon YK, Song $\mathrm{T}$, et al. Clarithromycin and amikacin vs. Clarithromycin and moxifloxacin for the treatment of post-acupuncture cutaneous infections due to Mycobacterium abscessus: a prospective observational study. Clin Microbiol Infect. 2011;17(7):1084-90.

25. Koh SJ, Song T, Choi JW, Lee JY, Song MK, Sung HY, et al. An outbreak of skin and soft tissue infection caused by Mycobacterium abscessus following acupuncture. Clin Microbiol Infect. 2010;16(7):895-901.

26. Lee WJ, Kang SM, Sung $\mathrm{H}$, Won $\mathrm{CH}$, Chang SE, Lee MW. Non-tuberculous mycobacterial infections of the skin: A retrospective study of 29 cases. J Dermatol. 2010;37(11):965-72.

27. Guevara-Patiño A, Sandoval de Mora M, Farreras A, Rivera-Olivero I, Fermin D, de Waard JH. Soft tissue infection due to Mycobacterium fortuitum following acupuncture: a case report and review of the literature. J Infect Dev Ctries. 2010;4(8):521-5.

28. Castro-Silva AN, Freire AO, Grinbaum RS, Elmor de Araújo MR, Abensur $H$, Araújo MR, et al. Cutaneous Mycobacterium haemophilum infection in a kidney transplant recipient after acupuncture treatment. Transpl Infect Dis. 2011;13(1):33-7.

29. Kim HS, Park IH, Seo SH, Han I, Cho HS. Multifocal infection of Mycobacterium other than tuberculosis mimicking a soft tissue tumor of the extremity. Orthopedics. 2011;34(12):e952-5.

30. Caspi O, Baranovitch O. When science meets medical tradition: what is needed for a dialogue on integrative medicine? J Altern Complement Med. 2009;15(5):579-83.

31. Australian Acupuncture Association Limited. Infection control guidelines for acupuncture. Queensland, Australia: Australian Acupuncture and Chinese Medicine Association; 1997.

32. Rutala WA, Shafer KM. General information on cleaning, disinfection and sterilization. In: Olmsted RN, editor. APIC infection control and applied epidemiology: principles and practice. St. Louis: Mosby; 1996. p. 1-17.
33. Centers for Disease Control and Prevention. Guideline for the prevention of intravascular catheterrelated infections. MMWR. 2002;51(RR-10):1-29.

34. Quattrin R, Pecile A, Conzut L, Majori S, Brusaferro $S$, GISIO Group. Infection control nurse: a national survey. J Nurs Manag. 2004;12(5):375-80. 